\title{
PELATIHAN DESIGN GRAFIS UNTUK PEMBERDAYAAN PEMUDA KARANG TARUNA DESA KARYABARU KECAMATAN BARAMBAI KABUPATEN BARITO KUALA PROVINSI KALIMANTAN SELATAN
}

\author{
Politeknik Negeri Banjarmasin 1,2,3,5 \\ Universitas Tidar ${ }^{4}$ \\ rozaq@ poliban.ac.id ${ }^{1}$ \\ rkelik@poliban.ac.id ${ }^{2}$ \\ riswan@poliban.ac.id ${ }^{3}$ \\ mujiarto_76@yahoo.co.id ${ }^{4}$ \\ firdaus.jauhari@poliban.ac.id ${ }^{5}$
}

Abdul Rozaq ${ }^{1}$, R.Kelik Hardinto ${ }^{2}$, Riswan Yunida ${ }^{3}$, Sigit Mujiarto ${ }^{4}$, Muhammad Firdaus Jauhari ${ }^{5}$

\begin{abstract}
ABSTRAK
Kegiatan pelatihan ini adalah sebagai penunjang bagi pemuda karang taruna desa Karyabaru kecamatan barambai kabupaten Barito Kuala dalam memahami lebih jauh lagi mengenai pelatihan Komputer, serta memperkenalkan metode "learn and fun" pada pelatihan tersebut. Sedangkan tujuan dari kegiatan ini adalah Melaksanakan Tri Dharma Perguruan Tinggi berupa Pengabdian Kepada Masyarakat.

Kemampuan dalam menyampaikan ide dan gagasan dalam upaya untuk membangun desa memerlukan dukungan teknologi informasi dan komunikasi yang dituangkan dalam bentuk spanduk, poster, undangan. Ini semua dapat dilakukan, jika kita dapat menguasai atau memiliki kemampuan design grafis yang baik. Pada kesempatan kali ini akan dilakukan transfer pengetahuan berupa penguasaan ketrampilan design grafis menggunakan software photoshop dan corel draw.

Dilakukan survey pendahuluan untuk melihat situasi kerja di lingkungan kelurahan/ aparatur desa dalam melakukan tugas dan fungsi (Tupoksi) serta kondisi masyarakat. Mengajak aparatur desa untuk menggerakkan masyarakat melalui organisasi yang ada di daerah atau desa/kelurahan Karya Baru. Mengkoordinir peserta yang berminat terhadap pelatihan-pelatihan yang sudah disiapkan oleh tim. Peserta mampu melaksanakan pelatihan design grafis dengan hasil yang dapat diimplementasikan dalam kegiatan keseharian menyangkut desain grafis.
\end{abstract}

Kata Kunci : pelatihan, desain, grafis 


\section{PENDAHULUAN}

Kewajiban Perguruan Tinggi sebagaimana dijelaskan dalam Tridharma Perguruan Tinggi adalah Pendidikan, Penelitian, dan Pengabdian Masyarakat. Salah satu kewajiban tersebut Pengabdian Masyarakat, hal ini dilaksanakan berkaitan dengan kepedulian setiap lembaga atau institusi yang bergerak di bidang Pendidikan khususnya Pendidikan Tinggi dengan mengikuti perkembangan dan kemajuan teknologi khususnya Indonesia sebagai satu negara yang memiliki potensi sumber daya alam dan manusia yang banyak belum dapat disetarakan dengan negaranegara maju.

Pusat Penelitian dan Pengabdian pada Masyarakat Poliban, merespon akan kepedulian tersebut dengan menyelenggarakan kegiatan Pengabdian Masyarakat berupa " PELATIHAN DESIGN GRAFIS UNTUK PEMBERDAYAAN PEMUDA KARANG TARUNA DESA KARYABARU KECAMATAN BARAMBAI KABUPATEN BARITO KUALA PROVINSI KALIMANTAN SELATAN".

\section{Maksud Dan Tujuan}

Maksud dari kegiatan pelatihan ini adalah sebagai penunjang bagi pemuda karang taruna desa Karyabaru kecamatan barambai kabupaten Barito Kuala dalam memahami lebih jauh lagi mengenai pelatihan Komputer, serta memperkenalkan metode "learn and fun" pada pelatihan tersebut.

Sedangkan tujuan dari kegiatan ini adalah Melaksanakan Tri Dharma Perguruan Tinggi berupa Pengabdian Kepada Masyarakat. TIM P3M Poliban menjalin kerjasama mitra dengan perangkat desa dan karang taruna desa Karya Baru Kecamatan Barambai Kabupaten Barito Kuala Provinsi Kalimantan Selatan

\section{Tujuan}

1. Mewujudkan kelembagaan dan manajemen organisasi yang kuat dan profesional dalam pelaksanaan kegiatan penelitian dan pengabdian kepada masyarakat

2. Terwujudnya kesadaran akan kewajiban Tri Dharma Perguruan Tinggi sebagai perubahan pola pikir civitas akademika

3. Meningkatnya kuantitas dan kualitas luaran penelitian dan pengabdian kepada masyarakat

4. Mewujudkan kegiatan penelitian dan pengabdian kepada masyarakat yang mampu memberikan solusi terhadap permasalahan yang dihadapi oleh masyarakat sebagai perwujudan pengaplikasian IPTEK

5. Terjalinnya kerjasama dengan berbagai pihak sehingga Poliban dipercaya sebagai perguruan tinggi yang mampu bersaing dengan perguruan tinggi lainnya 


\section{Sasaran}

Terciptanya standar mutu pendidikan yang relevan dengan kebutuhan pasar kerja, ilmu pengetahuan, dan teknologi, yaitu : (1) Tercapainya penemuan inovasi Penelitian luar biasa (inventor) (2) Tercapainya penyelenggaraan kegiatan kemasyarakatan. Dalam upaya mewujudkan mutu dan kuantitas riset serta penemuan yang relevan dengan agenda riset Politeknik Negeri Banjarmasin dan pemanfaatan IPTEKS bagi masyarakat melalui peningkatan:

1. Publikasi di tingkat nasional dan internasional

2. Kerjasama riset dengan lembaga pemerintah dan swasta, baik di dalam maupun luar negeri.

3. Perolehan dana hibah riset dari lembaga pemerintah dan swasta, baik di dalam maupun luar negeri.

4. Penemuan (inovasi)

5. Perolehan HKI produk riset

6. Buku Ajar

Seluruh riset unggulan POLIBAN adalah kajian interdisiplin yang berorientasi kepada dan berkontribusi nyata dalam penyelesaian sebagian masalah di masyarakat

\section{Analisis Situasi}

TIM P3M Poliban menjalin kerjasama mitra dengan perangkat desa dan karang taruna desa Karya Baru Kecamatan Barambai Kabupaten Barito Kuala Provinsi Kalimantan Selatan yang mempunyai wilayah 13,7 km2. Adapun alasan kami memilih mitra tersebut disebabkan berdasarkan hasil survei dan wawancara dengan pihak aparatur desa serta masyarakat setempat serta merupakan salah satu program yang direncanakan oleh desa tentang pelatihan design grafis untuk pemberdayaan pemuda sebagai solusi untuk mendesain secara komputerisasi informasi yang disampaikan misalkan (pengumuman, undangan, poster, spanduk dan lain-lain yang berkaitan dengan desain grafis, akan tetapi muncul permasalahan tentang ketidakmampuan dalam mewujudkan tesebut karena dana desa sudah tidak dapat digunakan untuk pembangunan infrastruktur yang diperlukan. Oleh karenanya dengan adanya kegiatan pelatihan design grafis, maka selanjutnya akan ditindak lanjuti sebagai satu program penerapan teknologi tepat guna.

\section{Permasalahan Mitra}

\section{a. Justifikasi pengusul bersama mitra dalam menentukan persoalan prioritas.}

Untuk mengidentifikasi permasalah mitra, perlu melalui perumusan masalah berdasarkan suatu analisa situasi yang didasarkan pada penjelasan kondisi eksternal dan internal mitra di atas. 


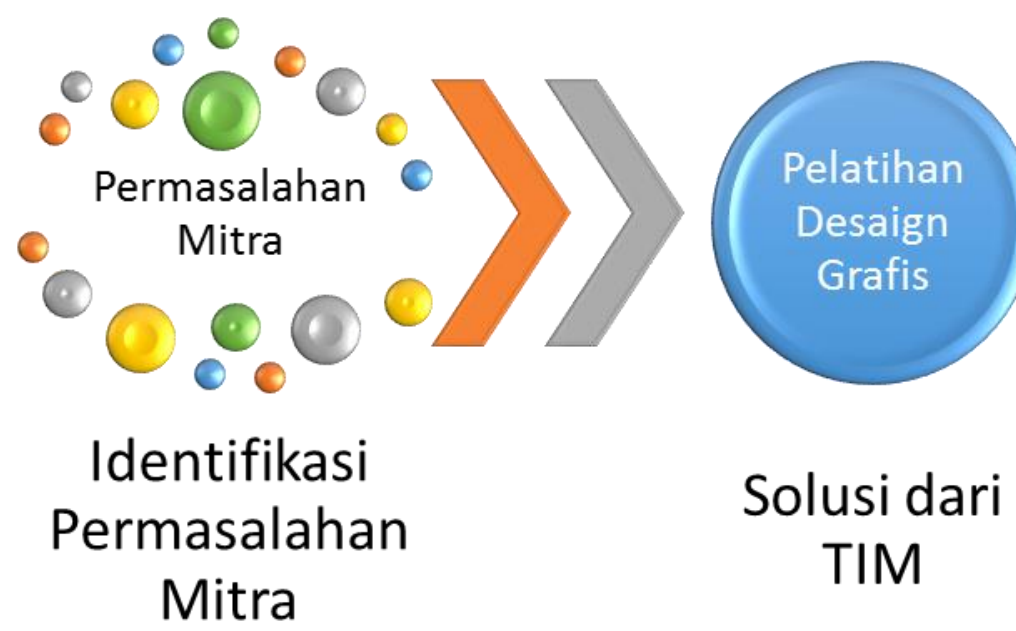

Gambar 1. Penggalian Ide untuk mencari permasalahan

Sumber : Data diolah tahun 2018

Rumusan Masalah :

1. Bagaimana menemukan permasalahan mitra dalam hal desain grafis untuk keperluan pembuatan spanduk, poster, dan undangan yang baik?

2. Bagaimana pelatihan design grafis untuk keperluan pembuatan spanduk, poster, dan undangan yang baik?

Adapun hasil analisa situasi dari mitra yang bersangkutan tergambar pada matriks analisis SWOT Permasalah Mitra sebagai berikut :

\section{Kekuatan}

1. Warga masyarakat usia produktif cukup banyak

2. Daerah pertanian cukup produktif

3. Semangat membangun Desa masih tinggi

\section{Kelemahan}

1. Komposisi tingkat pendidikan yang cukup rendah

2. Capaian pembangunan dalam peningkatan kesejahteraan masih cukup rendah

3. Infrastruktur masih kurang

\section{Peluang}

1. Lokasi yang relatif mudah diakses dari jalan Provinsi

3. Peluang pengelolaan pariwisata pertanian dan peternakan

4. Pengelolaan lahan gambut menjadi lebih bermanfaat

\section{Ancaman}

1. Tumbuhnya industri yang mengakibatkan lingkungan kurang tertata dan menjadi rusak.

2. Banyaknya pengembang perumahan yang mulai menjarah ke pedesaan 
3. Banyaknya bermunculan usaha di bidang desain grafis berasal dari luar daerah

\section{Strategi Kekuatan Ancaman}

1. Meningkatkan budaya "Technopreneurship " melalui penerapan teknologi Informasi dan komunikasi

2. Mendirikan usaha produktif bagi masyarakat melalui penerapan teknologi Informasi dan komunikasi dengan diversip ikasi usaha beragam

3. Mengembangkan potensi koperasi desa Karya Baru Kecamatan Barambai.

\section{Strategi Kelemahan dan Peluang}

1. Mengembangkan unit usaha di bawah koperasi desa yang produktif berdasarkan diseminasi teknologi;

2. Pemberdayaan ekonomi masyarakat menggunakan diseminasi hasil teknologi informasi dan komunikasi.

\section{b. Penerapan teknologi kemasyarakat}

Kemampuan dalam menyampaikan ide dan gagasan dalam upaya untuk membangun desa memerlukan dukungan teknologi informasi dan komunikasi yang dituangkan dalam bentuk spanduk, poster, undangan. Ini semua dapat dilakukan, jika kita dapat menguasai atau memiliki kemampuan design grafis yang baik. Pada kesempatan kali ini akan dilakukan transfer pengetahuan berupa penguasaan ketrampilan design grafis menggunakan software photoshop dan corel draw.

\section{c. Sasaran}

Sasaran keigatan adalah masyarakat usia produktif, termasuk taruna karya, kelompok bapak-bapak, para pemuda, kelompok petani, Kelompok RT/RW dalam melaksanakan kegiatan kewirausahaan serta program pemberdayaan masyarakat di wilayah desa Karya Baru Kecamatan Barambai Kabupaten Barito Kuala Provinsi Kalimantan Selatan.

\section{SOLUSI YANG DITAWARKAN}

\section{a. Tujuan dan Sasaran}

Menyediakan pilihan teknologi informasi dan komunikasi berupa kemampuan design grafis yang disesuaikan dengan kondisi masyarakat. Memberikan pembelajaran bersama teknologi tepat guna skala lokal yang selanjutnya ingin didorong untuk kapasitas dan skala lebih besar melalui pendekatan pemberdayaan masyarakat.

\section{b. Manfaat}

Mempermudah masyarakat membuat pilihan teknologi sesuai dengan kemampuan dan pengatahuan tentang penggunaan dan implementasi design grafis yang dapat dituangkan dalam bentuk spanduk, poster, dan undangan. Peralatan dapat disesuaikan dengan kondisi yang ada di lapangan.

\section{METODE PENDEKATAN YANG DITAWARKAN UNTUK MENYELESAIKAN PERSOALAN MITRA}

a. Pihak-pihak yang terlibat dalam kegiatan adalah: 
1) Anggota masyarakat yang terdiri dari kelompok/ organisasi, yaitu: Kelompok karang karuna dll.

2) Prosedur Kerja Untuk Mendukung Realisasi Metode Yang Ditawarkan.

a.) Tahapan 1

Dilakukan survey pendahuluan untuk melihat situasi kerja di lingkungan kelurahan/ aparatur desa dalam melakukan tugas dan fungsi (Tupoksi) serta kondisi masyarakat. Mengajak aparatur desa untuk menggerakkan masyarakat melalui organisasi yang ada di daerah atau desa/kelurahan Karya Baru. Mengkoordinir peserta yang berminat terhadap pelatihan-pelatihan yang sudah disiapkan oleh tim.

b.) Tahapan 2

terpilih masyarakat/peserta yang benar-benar mampu melaksanakan pelatihan design grafis. Dalam pendampingan setiap peserta wajib melakukan registrasi pada setiap sesi kegiatan yang dilaksanakan. Diharapkan Mitra dapat berpartisipasi dengan ditunjukkan oleh kehadiran minimal 85\%. Diakhir kegiatan dilaksanakan monitoring dan evaluasi dari kegiatan pelatihan ini, sehingga pada waktu yang akan datang dapat dilakukan pemetaan kebutuhan yang masih relevan dengan bidang peningkatkan kinerja organisasi desa Karya Baru melalui diklat bidang administrasi bisnis. Peserta yang sudah mengikuti pelatihan dapat mengimplementasikan bagaimana menentukan skala prioritas kerja yang produktif. Peserta mampu menerapkan bagaimana cara menangani masalah yang muncul di dunia usaha. Menghasilkan Masyarakat produktif dan wirausaha berbasis Teknologi Informasi dan Komunikasi terutama ketrampilan design grafis.

\section{HASIL DAN PEMBAHASAN}

\section{Perkenalan Dengan Corel Draw}

\section{CorelDRAW - The Popular Drawing Software}

CorelDRAW adalah sebuah drawing software yang sangat populer. Sebuah software yang serbaguna dan dimanfaatkan oleh para desainer dari berbagai aliran: seni murni, desain logo, desain ikon dan karakter, desain poster, brosur, kartu nama, cover buku dan sebagainya. Digemari oleh desainer cetak karena memiliki palet warna yang mendekati warna yang dihasilkan oleh mesin cetak, meskipun demikian CorelDRAW tidaklah cocok digunakan untuk layout isi buku. Pertama kali muncul pada tahun 1998. Popularitas dan penggunaannya yang begitu luas membuat software lain yang sejenis, sedikit banyak kemudian mengikuti tampilan dan cara penggunaannya, termasuk drawing software yang tidak berbayar (open source).

\section{Antarmuka CorelDRAW}


Setelah memberikan perintah untuk membuka CorelDRAW, mungkin saja akan muncul jendela dengan pertanyaan atau pilihan, klik saja ' $N$ ew', dan akan muncul antarmuka utama CorelDRAW. Tutorial ini menggunakan CorelDRAW versi X4 untuk pembahasannya. Jika versi yang anda miliki berbeda, jangan khawatir, secara garis besar antarmuka CorelDRAW tidak mengalami perubahan radikal dari satu versi ke versi berikutnya, sehingga informasi dalam tutorial ini masih dapat anda gunakan. Perbedaan yang ada adalah kemampuan baru yang ditambahkan setiap kenaikan versi, yang biasanya ditunjukkan oleh adanya tool baru pada toolbar atau menu baru, sehingga pada versi yang lebih lama dari X4, beberapa bagian antarmuka belum ada.

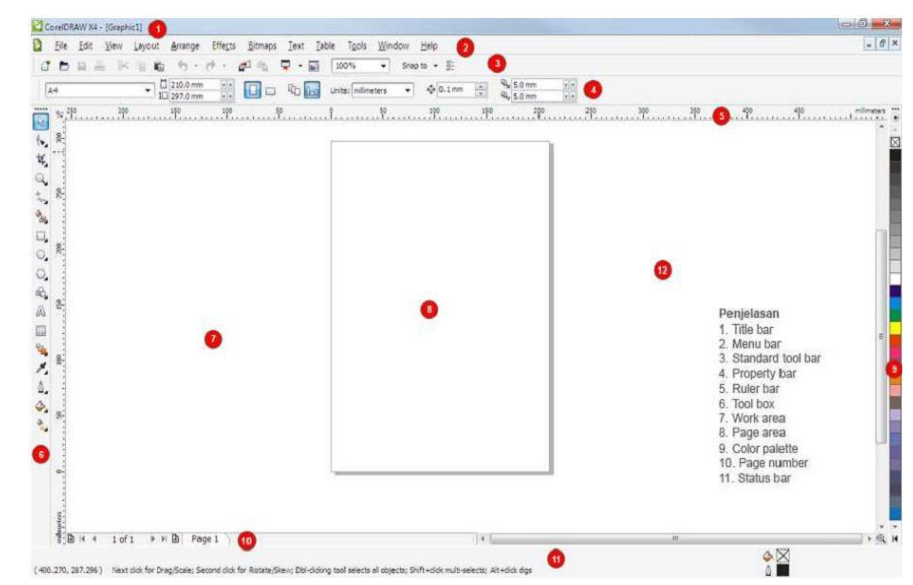

Gambar 2. Antar Muka CorelDraw

Bagian-bagian antarmuka CorelDRAW (nomor menunjuk pada ilustrasi gambar):

1. Title Bar

2. Menu Bar

Kumpulan menu yang digunakan untuk mengakses seluruh fungsi-fungsi yang ada pada CorelDraw, termasuk membuka - menyimpan file, efekefek, dan sebagainya.

3. Standard Toolbar

Kumpulan icon yang berfungsi untuk mengakses menu-menu umum yang paling sering dipakai. Berikut isi standard toolbar: 


\section{Property Bar}

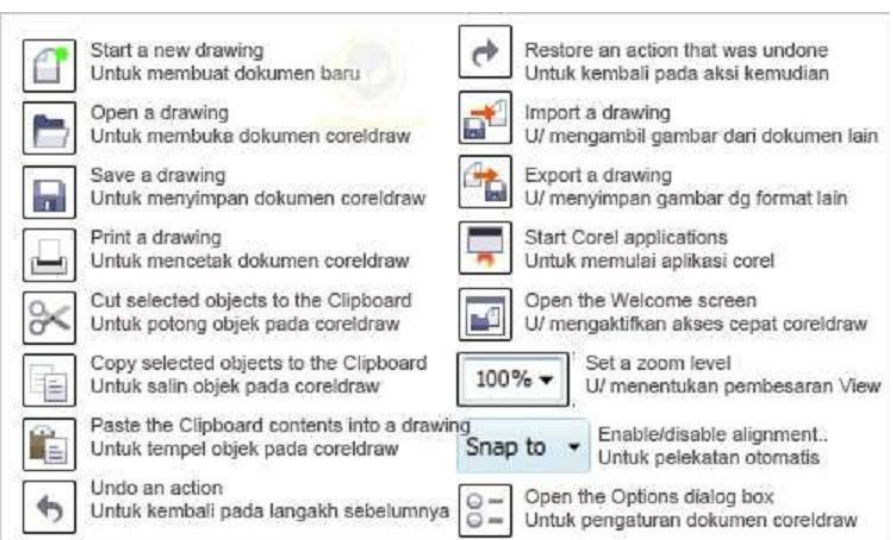

Gambar 3. Icon di CorelDraw

Berfungsi menampilkan pilihan properti dari sebuah fungsi toolbox yang tengah dipakai. Pada kondisi default (tool yang terpilih adalah pick tool panah putih, maka property bar akan berisi ukuran kertas bidang gambar, orientasi kertas, unit yang digunakan, dan sebagainya. Property bar akan selalu berubah tergantung dari tool yang kita pilih di toolbox.
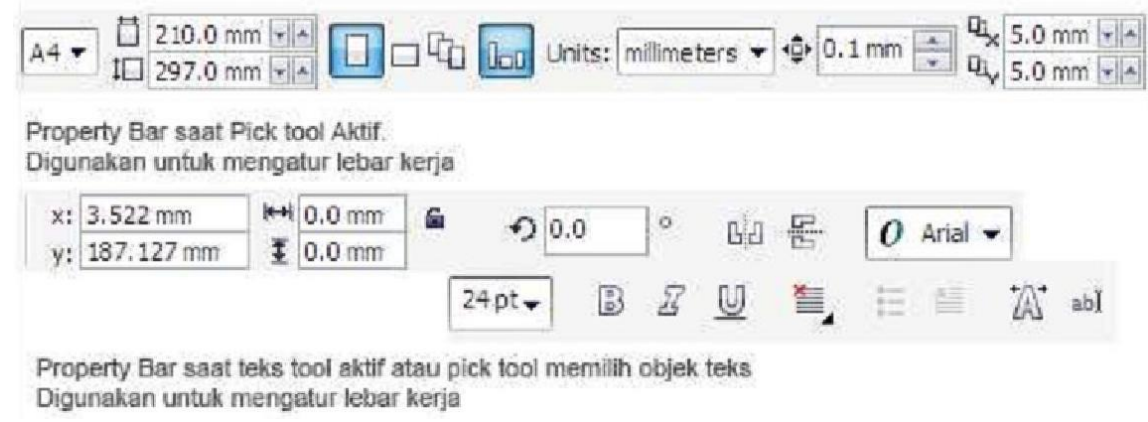

Gambar 1.4 Property Bar

\section{Ruler Bar}

6. Toolbox

Berisi pilihan tool dan mode menggambar. Klik pada sebuah ikon tool untuk menggunakannya, maka tombol ikon akan tampak seperti ditekan, dan tool tersebut siap kita gunakan pada bidang gambar. Kadang juga terdapat subtool yang dapat dimunculkan dengan menekan agak lama pada sebuah icon tool, kemudian klik pada sub tool yang tersedia. Isi Toolbox ditunjukkan pada halaman berikutnya. 


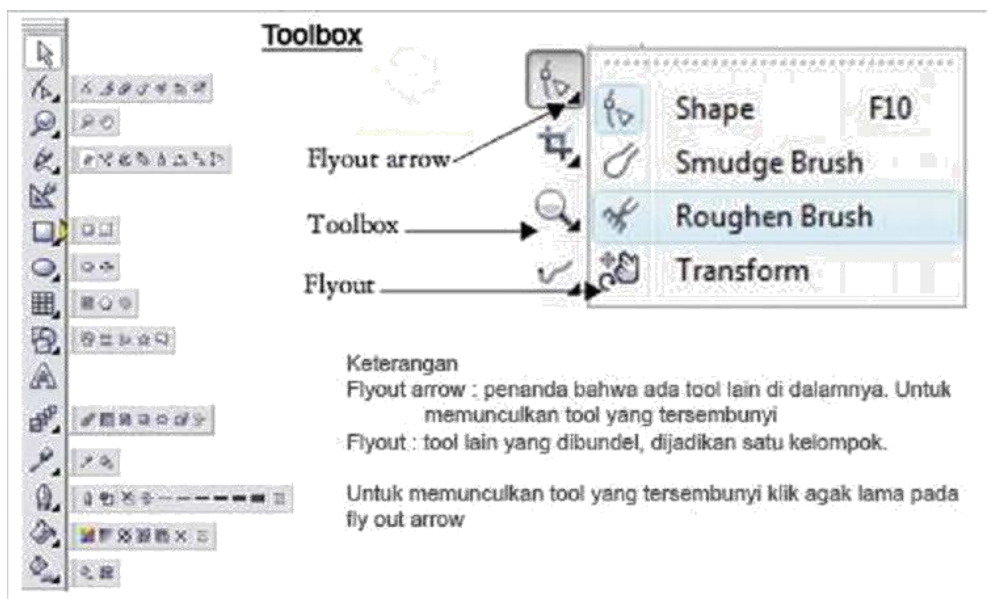

Gambar 5. Toolbox CorelDraw

7. Bidang Kerja

8. Bidang Gambar

Luasan bidang gambar dengan ukuran kertas tertentu yang dapat kita gunakan untuk mendesain gambar. Apa yang berada di luar tepi bidang gambar tidak akan ikut tercetak saat diprint.

9. Palet Warna

Digunakan untuk memilih warna yang akan kita pakai untuk mewarnai sebuah objek gambar. Klik kiri pada palet akan mengeset warna isian (fill) suatu objek, dan klik kanan pada palet akan mengeset warna tepi dan garis (line).

10.Penunjuk Halaman

\section{Status Bar}

Menunjukkan beberapa status penting dan event yang sedang terjadi, juga pada bagian kanan menunjukkan warna fill dan line sebuah objek.

12. Object Properties

Menampilkan setting yang dapat dipilih dari sebuah objek. Biasanya yang terdapat di sini adalah warna fill, warna garis, dan sebagainya untuk sebuah objek tertentu saja. 


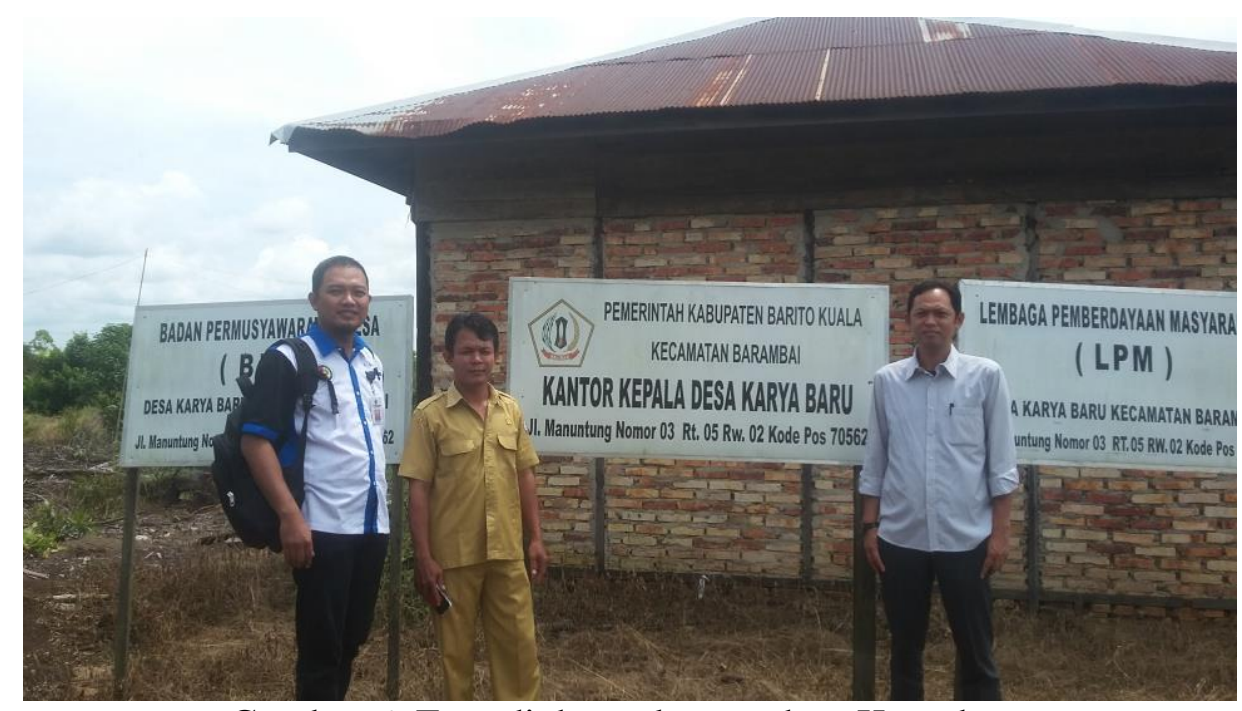

Gambar 6. Foto di depan kantor desa Karyabaru

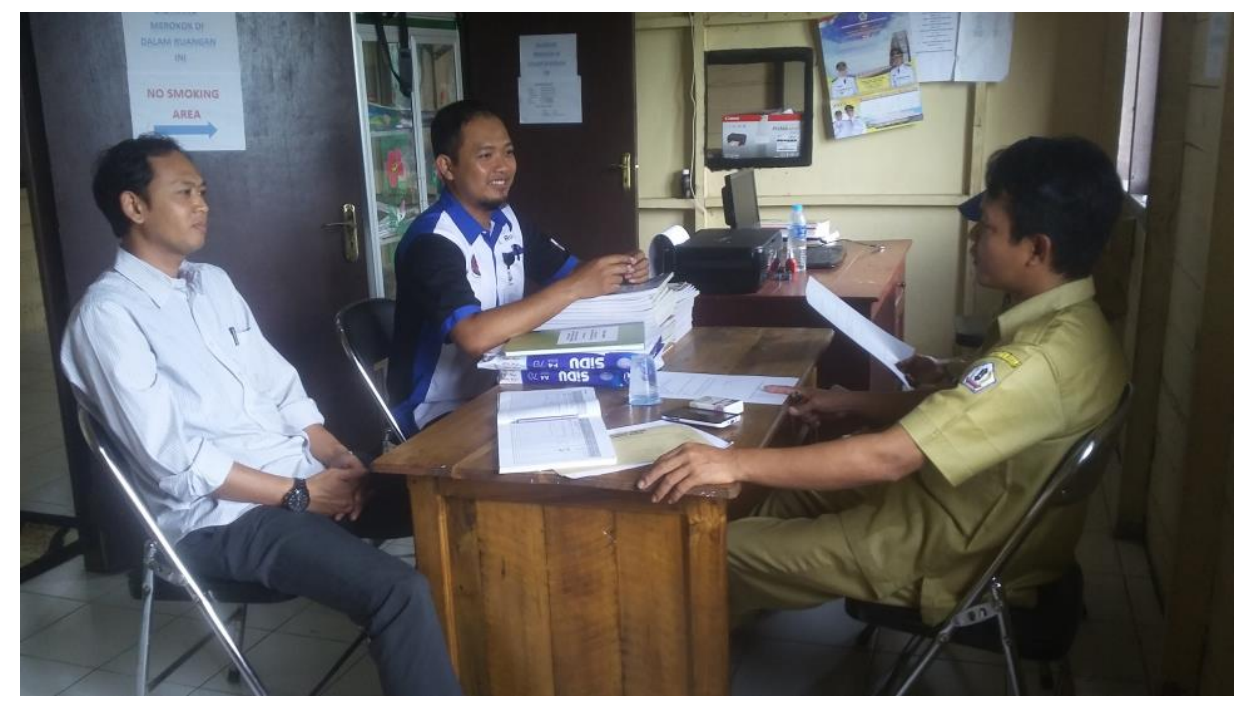

Gambar 7. Foto dengan perangkat desa Karyabaru 


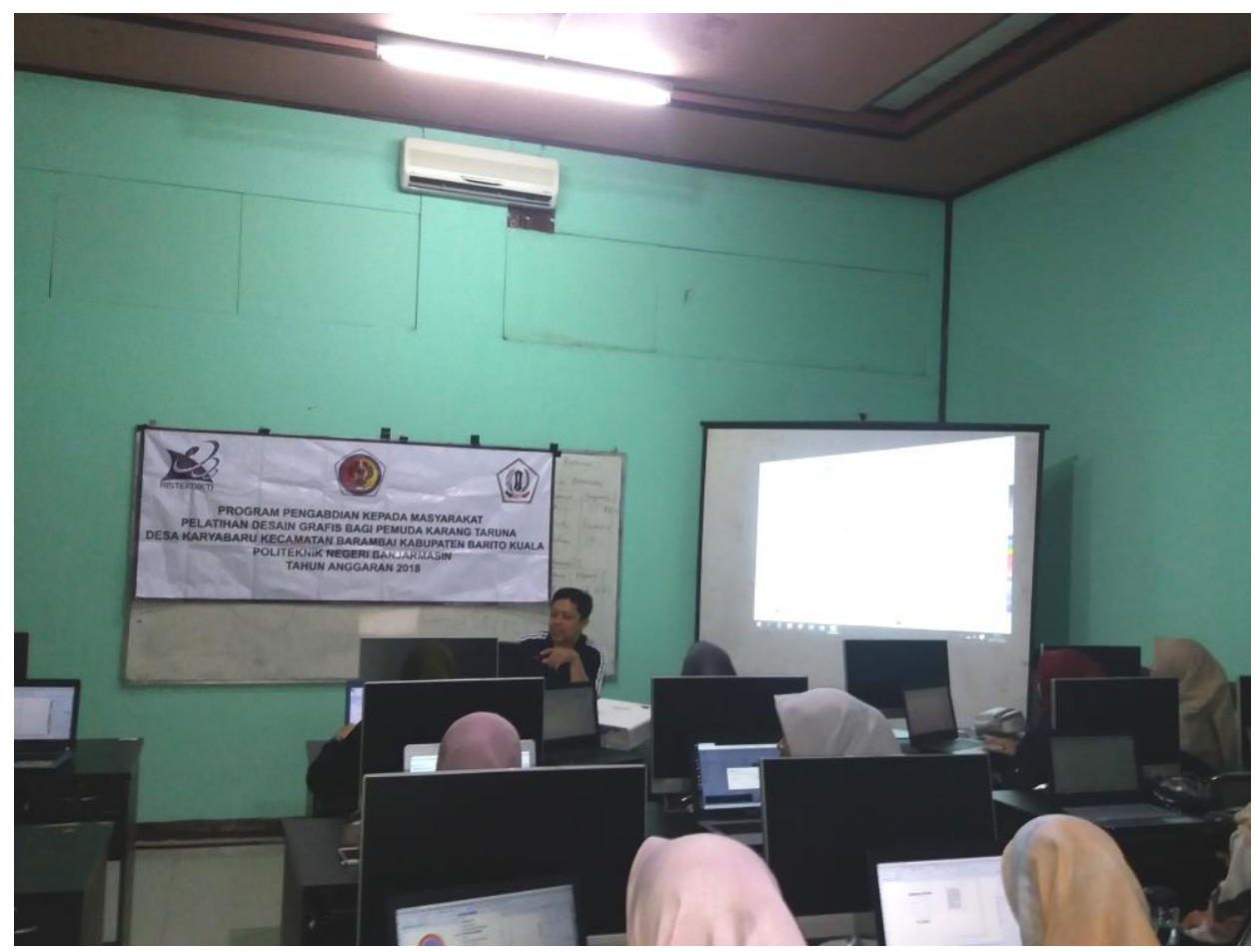

Gambar 8. Pelatihan desain grafis

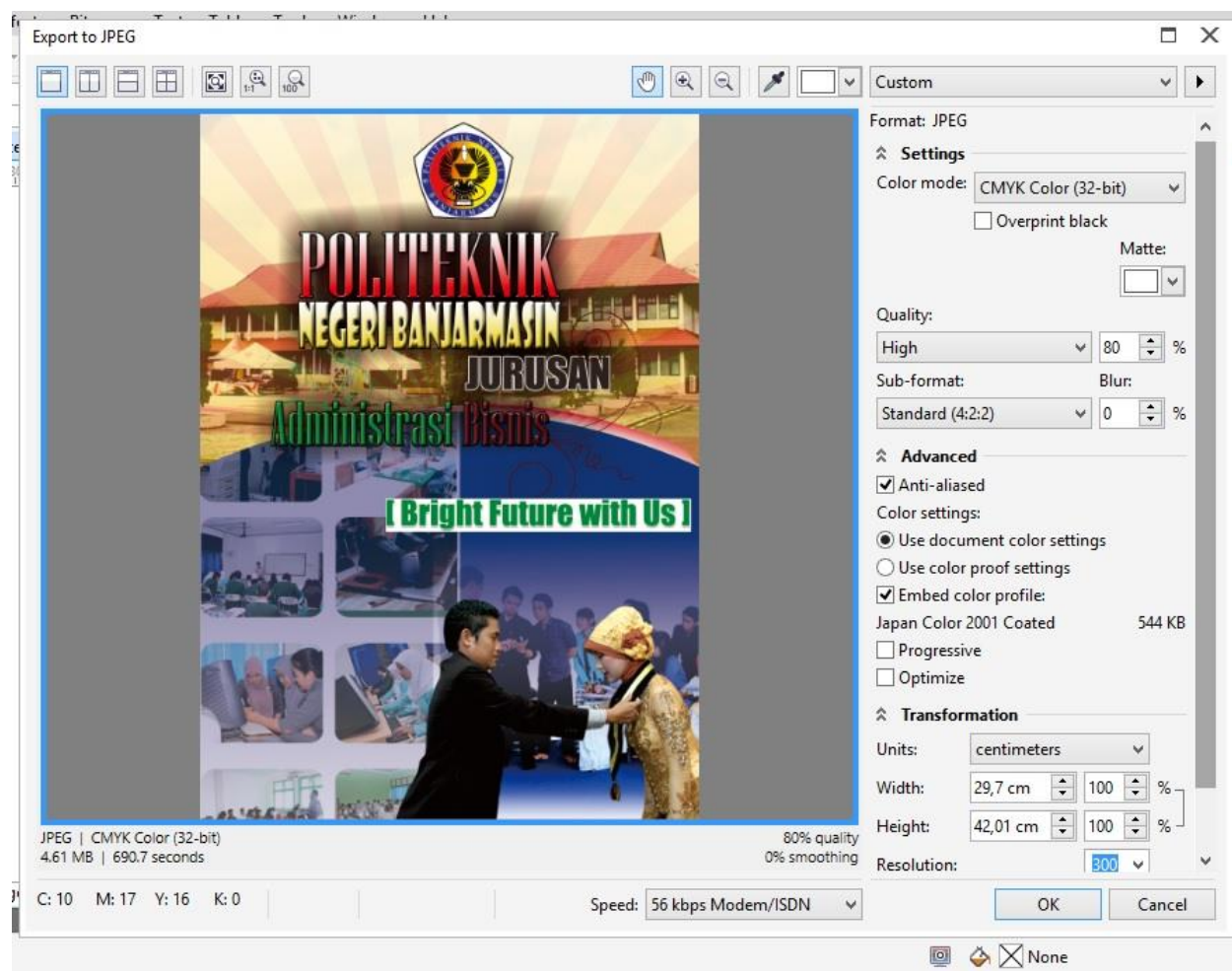

Gambar 9. Hasil desain

\section{KESIMPULAN}


Agar Terciptanya standar mutu pendidikan yang relevan dengan kebutuhan pasar kerja, ilmu pengetahuan, dan teknologi, yaitu : (1) Tercapainya penemuan ino vasi Penelitian luar biasa (inventor) (2) Tercapainya penyelenggaraan kegiatan kemasyarakatan. Hal ini dilaksanakan berkaitan dengan kepedulian setiap lembaga atau institusi yang bergerak di bidang Pendidikan khususnya Pendidikan Tinggi dengan mengikuti perkembangan dan kemajuan teknologi khususnya Indonesia sebagai satu negara yang memiliki potensi sumber daya alam dan manusia yang banyak belum dapat disetarakan dengan negara-negara maju, yaitu dengan menyelenggarakan kegiatan Pengabdian Masyarakat berupa " PELATIHAN DESIGN GRAFIS UNTUK PEMBERDAYAAN PEMUDA KARANG TARUNA DESA KARYABARU KECAMATAN BARAMBAI KABUPATEN BARITO KUALA PROVINSI KALIMANTAN SELATAN". Maksud dari kegiatan pelatihan ini adalah sebagai penunjang bagi pemuda karang taruna desa Karyabaru kecamatan barambai kabupaten Barito Kuala dalam memahami lebih jauh lagi mengenai pelatihan Komputer, serta memperkenalkan metode "learn and fun" pada pelatihan tersebut.

TIM P3M Poliban menjalin kerjasama mitra dengan perangkat desa dan karang taruna desa Karya Baru Kecamatan Barambai Kabupaten Barito Kuala Provinsi Kalimantan Selatan. Berdasarkan hasil survei dan wawancara dengan pihak aparatur desa serta masyarakat setempat serta merupakan salah satu program yang direncanakan oleh desa tentang pelatihan design grafis untuk pemberdayaan pemuda sebagai solusi untuk mendesain secara komputerisasi informasi yang disampaikan misalkan (pengumuman, undangan, poster, spanduk dan lain-lain yang berkaitan dengan desain grafis. Untuk mengidentifikasi permasalah mitra, perlu melalui perumusan masalah berdasarkan suatu analisa situasi yang didasarkan pada penjelasan kondisi eksternal dan internal mitra.

Solusi yang ditawarkan dengan menyediakan pilihan teknologi informasi dan komunikasi berupa kemampuan design grafis yang disesuaikan dengan kondisi masyarakat. Memberikan pembelajaran bersama teknologi tepat guna skala lokal yang selanjutnya ingin didorong untuk kapasitas dan skala lebih besar melalui pendekatan pemberdayaan masyarakat. Sehingga memberi mamfaat untuk Mempermudah masyarakat membuat pilihan teknologi sesuai dengan kemampuan dan pengatahuan tentang penggunaan dan implementasi design grafis yang dapat dituangkan dalam bentuk spanduk, poster, dan undangan. Peralatan dapat disesuaikan dengan kondisi yang ada di lapangan

\section{SARAN}

a. Diharapkan masyarakat usia produktif, termasuk taruna karya, kelompok bapak-bapak, para pemuda, kelompok petani, Kelompok RT/RW dalam melaksanakan kegiatan kewirausahaan serta program pemberdayaan masyarakat di wilayah desa Karya Baru Kecamatan Barambai Kabupaten Barito Kuala Provinsi Kalimantan Selatan.

b. Dengan adanya Pelatihan design grafis untuk pemberdayaan pemuda karang taruna desa karyabaru kecamatan barambai kabupaten barito kuala provinsi kalimantan selatan masarakat dapat membuat peluang usaha dibidang 
percetakan kegiatan kewirausahaan serta program pemberdayaan masyarakat di wilayah desa Karya Baru Kecamatan Barambai Kabupaten Barito Kuala.

c. Ditingkatkan lagi untuk pelatihan serta program pemberdayaan masyarakat, dalam memahami lebih jauh lagi mengenai pelatihan Komputer dengan kemampuan dan pengatahuan tentang penggunaan dan implementasi design grafis sehingga masyarakat bisa lebih produktif.pada bagian ini. Ucapan terima kasih juga dapat ditujukan untuk pihak pemberi dana pengabdian.

\section{DAFTAR PUSTAKA}

Purwanto, B., Tata Letak \& Tipografi dalam desain Grafis. (pg. 164)

Kusrianto, A. 2008. Teknik Menggambar Desain Grafis CorelDRAW X4. Jakarta. Elex Media Komputindo

Rohanto, U., 2010. Mahir Mendesain Sampul Buku dengan Coreldraw X5. Yogyakarta. Skripta Media Creative

Rustan, S., 2011. Font dan Tipografi. Jakarta: PT. Gramedia Pustaka Utama.

Arti-warna-desain-grafis. 2010. Arti warna. Diakses pada 6 Juni 2011. WWW : desain_warna.com

Belajar-desain-grafis. 2009. Desain Cover Buku. Diakses pada 5 Juni 2011. WWW : belajar-desain-grafis.blogspot.com 